American Journal of Applied Sciences 7 (3): 315-322, 2010

ISSN 1546-9239

(C) 2010Science Publications

\title{
Evaluation of Lead, Cadmium and Copper Concentrations in Bee Honey and Edible Molasses
}

\author{
Ahmed Hassan, Mahmoud A.A. Ghandour, Azza M.M. Ali and Hazim. A. Mahran \\ Department of Chemistry, Faculty of Science, Assiut University, 71516, Assiut, Egypt
}

\begin{abstract}
Problem statement: Content of Cadmium, lead and copper in 26 bee honey samples from different places of Assiut governorate (south of Egypt) and three different botanical origins (Clover, Multi-flower and Citrus) in addition to four edible molasses samples from Egypt market were evaluated by Differential Pulse Anodic Stripping Voltammetry (DPASV) in Briton-Robinson buffer solution at $\mathrm{pH} \sim 2.1$, as well as atomic absorption spectrometry after wet digestion. Approach: The optimal deposition potentials and times for the detection of these metal ions in all sample solutions have been studied. Results: The concentration of each metal ion was determined by the standard addition method. The statistical parameters i.e., slope, standard deviation, correlation coefficient and confidence have been calculated. Conclusion/Recommendations: The results obtained using stripping voltammetry indicate that the average concentration of $\mathrm{Cu}$ ions ranged from $0.085-0.987 \mu \mathrm{g} \mathrm{g}^{-1}$. In addition, the average concentrations of $\mathrm{Cd}$ and $\mathrm{Pb}$ ions ranged 0.001-0.077 and 0.006-1.640 $\mu \mathrm{g} \mathrm{g}^{-1}$; respectively. On the other hand, the average concentrations obtained using atomic absorption spectrometry of the same element mentioned above ranged from $0.077-0.991 \mu \mathrm{g} \mathrm{g}^{-1}$ for $\mathrm{Cu} ; 0.001-$ $0.087 \mu \mathrm{g} \mathrm{g}^{-1}$ for $\mathrm{Cd}$ and $0.007-1.650 \mu \mathrm{g} \mathrm{g}^{-1}$ for $\mathrm{Pb}$.
\end{abstract}

Key words: Stripping voltammetry, honey, molasses, biological indicator

\section{INTRODUCTION}

Honey is a quick, safe and natural energy giver because its simple sugar is quickly absorbed into the blood stream, honey is an easily digestible foodstuff containing a range of nutritiously important complementary elements. Besides a high content of a range of saccharides, there are also organic acids, amino acids, mineral matters, colors, aromatic substances and a trace amount of fats (Bogdanov et al., 1999). Besides these, honey contains very valuable but unstable compounds, such as enzymes, substance of hormonal character, some vitamins and a few minor compounds (Yilmaz and Yavuz, 1999). Honey contaminations by heavy metals (especially $\mathrm{Pd}, \mathrm{Cd}$ and $\mathrm{Cu}$ ) that are widely spread in our environment are the result of:

- The location of colonies in industrial zones or other areas with considerable air pollution such as cities, can lead to considerable contamination of various hive products with noxious or toxic chemical. Agricultural use of toxic chemicals is another common and very likely source of contamination; further contamination may results from dirty water source and non-floral sugar source (Antonescu and Mateescu, 2001)
- The use of unpleasant smelling chemicals to drive bees away is a technique preferred by many beekeepers because it is quick and easy (Dadant and Sons, 1992)

- Containers previously used for toxic chemicals, oil or petroleum products or vessels doesn't manufacture for food preservation should never be used for storing honey, because it is become a source of honey contamination by heavy metals

Several authors have indicated that bee and their products may be used as biological indicator (Fernandez et al., 1994; Sanna et al., 2000; Buldini et al., 2001; Bogdanov et al., 2003; Fredes and Montenegro, 2006).

Copper is both vital and toxic for many biological system, it is critical for energy production in the cells, also involved in nerve conduction, connective tissue, the cardiovascular system and the immune system. Copper is closely related to estrogen metabolism and is required for women's fertility and to maintain pregnancy. Copper stimulates production of the neurotransmitters epinephrine, norepinephrine and dopamine. It is also required for monoamine oxidase, an enzyme related to serotonin production. Also excess

Corresponding Author: Ahmed Hassan, Department of Chemistry, Faculty of Science, Assiut University, 71516, Assiut, Egypt Tel: 002/0882318504 Fax: 002/0882342708 
copper may be absorbed in the intestinal tissues which lead to intestinal disorders, impaired healing and reduced resistance to infections (Wilson, 1998).

Cadmium is one of the few elements that have no constructive purpose in the human body. This elements and solution of its compound are extremely toxic even in low concentration and will bioaccumulation in organisms and ecosystems. One possible reason for its toxicity is that it interferes with the action of zinccontaining enzymes. Cadmium may also interfere with biological processes containing magnesium and calcium (Lide, 2005; Clarkson, 1988). Its toxicity threatens the health of the body by weakened immune system, Kidney disease and live damage, Effects may include emphysema, cancer and a shortened life span (Lide, 2005).

Lead has no know biological role in the body. Its toxicity comes from its ability to mimic other biologically important metals, the most notable of which are calcium, iron and zinc. Lead is able to bind to and interact with the same proteins and molecules as these metals, but after displacement, those molecules function differently and fail to carry out the same reactions, such as in producing enzymes necessary for certain biological processes. Most lead poisoning symptoms are thought to occur by interfering with an essential enzyme Delta-aminolevulinic acid dehydratase, or ALAD (is a zinc-binding protein which is important in the biosynthesis of heme, the cofactor found in hemoglobin) (Simon and Hudes, 1999). It inhibits several enzymes critical to the synthesis of heme, causing a decrease in blood hemoglobin and interferes with a hormonal form of vitamin $\mathrm{D}$, which affects multiple processes in the body, including cell maturation and skeletal growth. Lead can also cause hypertension, reproductive toxicity and developmental effects. Lead exposure can lead to renal effects such as fanconi-like syndromes, chronic nephropathy and gout (Batuman et al., 1981).

Recently, several methods of analysis were done for determination of cadmium, lead and copper, e.g., by stripping voltammetry (Sanna et al., 2000; Buldini et al., 2001; Li et al., 1995), potentiometric stripping analysis (Munoz and Palmero, 2006), atomic absorption spectroscopy (Bogdanov et al., 1999; Antonescu and Mateescu,2001; Vinaset al., 1997; Rodriguez-García et al., 2003; Taddia et al., 2004; Tuzen and Soylak, 2005; Ajtony et al., 2007), inductively coupled plasma atomic emissionspectrometry(Caroliet al., 1999; Ioannidou et al., 2005; Terrab et al., 2005). Inductively coupled plasma mass spectrometry (Packer and Gine, 2001), inductively coupled plasma optical emission spectrometry (Fredes and Montenegro, 2006; Lachman et al., 2007), total reflection X-ray fluorescence spectrometry (Kump et al., 1996).

\section{MATERIALS AND METHODS}

Apparatus: All glassware was soaked in $10 \%(\mathrm{v} / \mathrm{v})$ $\mathrm{HNO}_{3}$ for $24 \mathrm{~h}$ and rinsed three times with distilled water and then in redistilled water before use:

- Polarographic analyzer/stripping voltammeter. Anodic differential pulse stripping voltammograms were recorded with an EG and G. Princeton Applied Research Crop. (PAR; Princeton, NJ) model 264 A stripping analyzer, coupled with a PAR 303 A Hanging Mercury Drop Electrode (HMDE). The polarographic cell (PAR Model $\mathrm{K} 0060$ ) was fitted with $\mathrm{Ag} / \mathrm{AgCl}$ saturated $\mathrm{KCl}$ and used as a reference electrode with a platinum wire as a counter (auxiliary) electrode. A PAR 305 magnetic stirrer was connected to the 303A SMDE. A PAR Model RE 0151X-Y recorder was used to collect experimental data. Before measurements the sample solution was deaereated by bubbling for 16 minutes with nitrogen. During measurements, an inert atmosphere over the solution was maintained by flushing with nitrogen. During the deposition step, the solution was stirred automatically, followed by a quiescent period of $15 \mathrm{sec}$ before scanning

- PH was measured with a Fischer Scientific (Pittsburgh, PA, USA) Digital pH Meter Model 810

- GBC 906 atomic absorption spectrophotometer was used for $\mathrm{Cu}(\mathrm{II})$ measurement at Wavelength $324.7 \mathrm{~nm}$, band-pass $0.7 \mathrm{~nm}$ and lamp current $6.0 \mathrm{~mA}$ and a AA-6800 Shimadzu (GFA-EX7) Graphite Furnace atomic absorption spectrophotometer was used for $\mathrm{Cd}(\mathrm{II})$ and $\mathrm{Pb}$ (II) determination at band-pass $0.7 \mathrm{~nm}$, lamp current $8.0 \mathrm{~mA}$ and Wavelength 228.9 and $283.2 \mathrm{~nm}$ respectively

Solution and reagents: All reagents are of analytical grade. The following solutions were prepared with bidistilled water:

- Solution of each $\mathrm{Cd}(\mathrm{II}), \mathrm{Pb}(\mathrm{II})$ and $\mathrm{Cu}$ (II) were prepared respectively by dissolving the required amounts of $\mathrm{Cd}\left(\mathrm{NO}_{3}\right)_{2} \cdot 4 \mathrm{H}_{2} \mathrm{O}, \quad \mathrm{Pb}\left(\mathrm{NO}_{3}\right)$ and $\mathrm{Cu}\left(\mathrm{NO}_{3}\right)_{2} \cdot 2 \mathrm{H}_{2} \mathrm{O}$ in bidistilled water. The resulting solutions were then standardized (Vogel and Basset, 1978). Solutions of lower concentrations were prepared by accurate dilution 
Am. J. Applied Sci., 7 (3): 315-322, 2010

Table 1: The sources and cadmium content of different clover $\left(\mathrm{BC}_{\mathrm{x}}\right)$, multi-flower $\left(\mathrm{MC}_{\mathrm{x}}\right)$ and citrus $\left(\mathrm{OC}_{\mathrm{x}}\right)$ honey samples and edible molasses samples $\left(\mathrm{EM}_{\mathrm{x}}\right)($ a mean value \pm standard deviation for $\mathrm{n}=5$ at the $95 \%$ confidence level $)$

\begin{tabular}{|c|c|c|c|c|c|c|c|}
\hline \multirow[b]{3}{*}{$\begin{array}{l}\text { Samples } \\
\text { number }\end{array}$} & \multirow[b]{3}{*}{$\begin{array}{l}\text { Geog. } \\
\text { sources }\end{array}$} & \multirow[b]{3}{*}{$\mathrm{T}_{\mathrm{d}}(\mathrm{sec})$} & \multirow{3}{*}{$\begin{array}{l}\text { Cadmium content } \\
(\text { mean } \pm \mathrm{SD}) \\
\mu \mathrm{g} \mathrm{g}^{-1}\end{array}$} & \multicolumn{3}{|c|}{ Regression parameter } & \multirow{3}{*}{$\begin{array}{l}\text { Cadmium content } \\
\left(\text { mean } \pm \text { SD) } \mu \mathrm{g} \mathrm{g}^{-1}\right. \\
(\text { GFAAS })\end{array}$} \\
\hline & & & & \multirow[b]{2}{*}{$\begin{array}{l}\text { Correction } \\
\text { coefficient }\end{array}$} & \multicolumn{2}{|c|}{ Confidence } & \\
\hline & & & & & Higher & Lower & \\
\hline$\overline{\mathrm{BC}_{1}}$ & Assiut & 120 & $0.027 \pm 0.00600$ & 0.9998 & 0.0350 & 0.0190 & $0.030 \pm 0.006$ \\
\hline $\mathrm{BC}_{2}$ & Sedfa & 45 & $0.055 \pm 0.00300$ & 0.9996 & 0.0590 & 0.0510 & $0.051 \pm 0.001$ \\
\hline $\mathrm{BC}_{3}$ & Abutig & 90 & $0.042 \pm 0.00500$ & 0.9993 & 0.0480 & 0.0360 & $0.044 \pm 0.007$ \\
\hline $\mathrm{BC}_{4}$ & Dairut & 90 & $0.052 \pm 0.00300$ & 0.9995 & 0.0560 & 0.0520 & $0.055 \pm 0.004$ \\
\hline $\mathrm{BC}_{5}$ & Al-Qusiya & 120 & $0.029 \pm 0.00200$ & 0.9999 & 0.0320 & 0.0270 & $0.030 \pm 0.001$ \\
\hline $\mathrm{BC}_{6}$ & Manfalut & 120 & $0.042 \pm 0.00600$ & 0.9998 & 0.0490 & 0.0350 & $0.044 \pm 0.002$ \\
\hline $\mathrm{BC}_{7}$ & Al-Ghanayem & 60 & $0.013 \pm 0.00100$ & 0.9998 & 0.0140 & 0.0120 & $0.014 \pm 0.001$ \\
\hline $\mathrm{BC}_{8}$ & Abnub & 120 & $0.024 \pm 0.00100$ & 0.9999 & 0.0250 & 0.0230 & $0.028 \pm 0.005$ \\
\hline $\mathrm{BC}_{9}$ & Sahil Salem & 120 & $0.022 \pm 0.00200$ & 0.9996 & 0.0250 & 0.0190 & $0.021 \pm 0.002$ \\
\hline $\mathrm{BC}_{10}$ & Al-Badary & 90 & $0.047 \pm 0.00200$ & 0.9995 & 0.0490 & 0.0450 & $0.052 \pm 0.005$ \\
\hline $\mathrm{BC}_{11}$ & Al-Fateh & 30 & $0.042 \pm 0.00300$ & 0.9995 & 0.0460 & 0.0380 & $0.043 \pm 0.008$ \\
\hline $\mathrm{BC}_{12}$ & Mangapad & 120 & $0.012 \pm 0.00100$ & 0.9992 & 0.0130 & 0.0110 & $0.013 \pm 0.003$ \\
\hline $\mathrm{MC}_{1}$ & Assiut & 120 & $0.013 \pm 0.00100$ & 0.9992 & 0.0140 & 0.0120 & $0.012 \pm 0.001$ \\
\hline $\mathrm{MC}_{2}$ & Sedfa & 120 & $0.023 \pm 0.00100$ & 1.0000 & 0.0240 & 0.0220 & $0.026 \pm 0.006$ \\
\hline $\mathrm{MC}_{3}$ & Abutig & 45 & $0.033 \pm 0.00100$ & 0.9999 & 0.0340 & 0.0320 & $0.030 \pm 0.009$ \\
\hline $\mathrm{MC}_{4}$ & Dairut & 120 & $0.051 \pm 0.00200$ & 0.9993 & 0.0530 & 0.0480 & $0.051 \pm 0.002$ \\
\hline $\mathrm{MC}_{5}$ & Al-Qusiya & 120 & $0.043 \pm 0.00200$ & 0.9992 & 0.0460 & 0.0410 & $0.047 \pm 0.008$ \\
\hline $\mathrm{MC}_{6}$ & Manfalut & 30 & $0.077 \pm 0.00400$ & 0.9997 & 0.0820 & 0.0720 & $0.087 \pm 0.005$ \\
\hline $\mathrm{MC}_{7}$ & Al-Ghanayem & 120 & $0.0044 \pm 0.0001$ & 1.0000 & 0.0045 & 0.0043 & $0.005 \pm 0.001$ \\
\hline $\mathrm{MC}_{8}$ & Abnub & 60 & $0.0067 \pm 0.0003$ & 0.9992 & 0.0070 & 0.0063 & $0.007 \pm 0.001$ \\
\hline $\mathrm{MC}_{9}$ & Sahil Salem & 120 & $0.014 \pm 0.00100$ & 0.9993 & 0.0150 & 0.0130 & $0.013 \pm 0.005$ \\
\hline $\mathrm{MC}_{10}$ & Al-Badary & 60 & $0.016 \pm 0.00200$ & 0.9997 & 0.0190 & 0.0140 & $0.015 \pm 0.002$ \\
\hline $\mathrm{MC}_{11}$ & Al-Fateh & 60 & $0.008 \pm 0.00100$ & 0.9996 & 0.0090 & 0.0070 & $0.008 \pm 0.001$ \\
\hline $\mathrm{MC}_{12}$ & Mangapad & 120 & $0.067 \pm 0.00300$ & 0.9991 & 0.0710 & 0.0630 & $0.070 \pm 0.003$ \\
\hline $\mathrm{OC}_{1}$ & Sahil Salem & 120 & $0.048 \pm 0.00300$ & 0.9997 & 0.0520 & 0.0440 & $0.050 \pm 0.001$ \\
\hline $\mathrm{OC}_{2}$ & Al-Badary & 30 & $0.055 \pm 0.00600$ & 0.9998 & 0.0630 & 0.0480 & $0.052 \pm 0.007$ \\
\hline $\mathrm{EM}_{1}$ & $\begin{array}{l}\text { Al-Hana } \\
\text { Al-Karma, Minia } \\
\text { Dahab }\end{array}$ & 60 & $0.066 \pm 0.00700$ & 0.9995 & 0.0750 & 0.0570 & $0.068 \pm 0.002$ \\
\hline $\mathrm{EM}_{2}$ & $\begin{array}{l}\text { El-Seid, Mallawi, } \\
\text { Minia }\end{array}$ & 120 & $0.001 \pm 0.000100$ & 0.9992 & 0.0011 & 0.0009 & $0.001 \pm 0.0001$ \\
\hline $\mathrm{EM}_{3}$ & $\begin{array}{l}\text { El-Kother } \\
\text { Al-Khlood, Qena }\end{array}$ & 90 & $0.061 \pm 0.00200$ & 0.9994 & 0.0640 & 0.0590 & $0.061 \pm 0.0060$ \\
\hline $\mathrm{EM}_{4}$ & $\begin{array}{l}\text { Al-Temsah } \\
\text { Al-Temsah, Tanta }\end{array}$ & 120 & $0.010 \pm 0.00100$ & 0.9995 & 0.0110 & 0.0090 & $0.010 \pm 0.0030$ \\
\hline
\end{tabular}

- Briton-Robinson buffer solution was prepared by dissolving $201 \mu \mathrm{L}$ glacial acetic acid (AnalaR), $240 \mu \mathrm{L}$ phosphoric acid (Merck) and $433 \mathrm{mg}$ boric acid (BDH) in $500 \mathrm{ml}$ measuring flask with bidistilled water (Ensafi et al., 2004).

Honey samples: Twenty-six bee honey samples were collected from Assiut governorate (south of Egypt) and four edible molasses as shown in Table 1.

Samples were collected in glass bottles and stored in dark prior to analysis.

Sample preparation: One gram of sample was treated with $10 \mathrm{~mL}$ of concentrated nitric acid, in a beaker, heating until nearly dry. This procedure was repeated with $15 \mathrm{~mL}$ of a $2: 1 \quad\left(\mathrm{HNO}_{3} / \mathrm{HClO}_{4}\right)$ mixture until complete mineralization. The residue was dissolved, at room temperature, in $1 \mathrm{ml}$ of $1 \mathrm{M}$ nitric acid, transferred to a $100 \mathrm{~mL}$ volumetric flask and diluted with bidistilled water (Fernandez-Torres et al., 2005). A control reagent blank was prepared in the same manner to determine the ultra trace impurities using the standard addition method as already used for the sample.

Analytical procedure: the following parameters were used to perform Differential Pulse Anodic Stripping Voltammetry (DPASV). Scan rate $10 \mathrm{mVs}^{-1}$ with duration for $1 \mathrm{sec}$ and pulse amplitude $(\Delta \mathrm{E}) 25 \mathrm{mV}$.

For determination of $\mathrm{Cd}(\mathrm{II}), \mathrm{Pb}(\mathrm{II})$ and $\mathrm{Cu}(\mathrm{II})$ in bee honey and edible molasses samples in the same cell. $5 \mathrm{~mL}$ of each sample solution and $1 \mathrm{~mL}$ of $0.028 \mathrm{M}$ Briton-Robinson buffer solution as supporting electrolyte were transferred into the electrolysis cell and completed to $10 \mathrm{~mL}$ using bidistilled water $(\mathrm{pH} \sim 2.1)$. 
The solution was deaereated by passing pure nitrogen for $16 \mathrm{~min}$. The deposition potential were controlled at $(-0.75,-0.55$ and $-0.25 \mathrm{~V} \mathrm{Vs} \mathrm{Ag} / \mathrm{AgCl}$ saturated $\mathrm{KCl}$ respectively) and applied to a fresh mercury drop while the solution was stirred. After the deposition step and further $15 \mathrm{sec}$. (equilibrium time) the voltammogram was recorded.

Different concentration from the standard metal ion (individually) were added to the cell using an automatic pipette (Volac 10-100 $\mu \mathrm{L}$ ), while keeping the deposition time constant. The solution was stirred and purged with nitrogen for $30 \mathrm{sec}$. after each spike. The concentration of each $\mathrm{Cd}(\mathrm{II}), \mathrm{Pb}$ (II) and $\mathrm{Cu}$ (II) in the electrolytic cell was calculated in the sample solutions by using standard addition method, Then the concentration in $\mu \mathrm{g} \mathrm{g}^{-1}$ of each bee honey and edible molasses samples were calculated.

\section{RESULTS AND DISCUSSION}

In order to set the optimal condition of the three cations, preliminary measurements were made to obtain the highest peak signal for metal ions $\mathrm{Cd}(\mathrm{II}), \mathrm{Pb}$ (II) and $\mathrm{Cu}(\mathrm{II})$ in solution samples. It was noticed that, BritonRobinson buffer solution ( $\mathrm{pH} \sim 2.1$ ) gave promising results for the determination of $\mathrm{Cd}, \mathrm{Pb}$ and $\mathrm{Cu}$ ions.

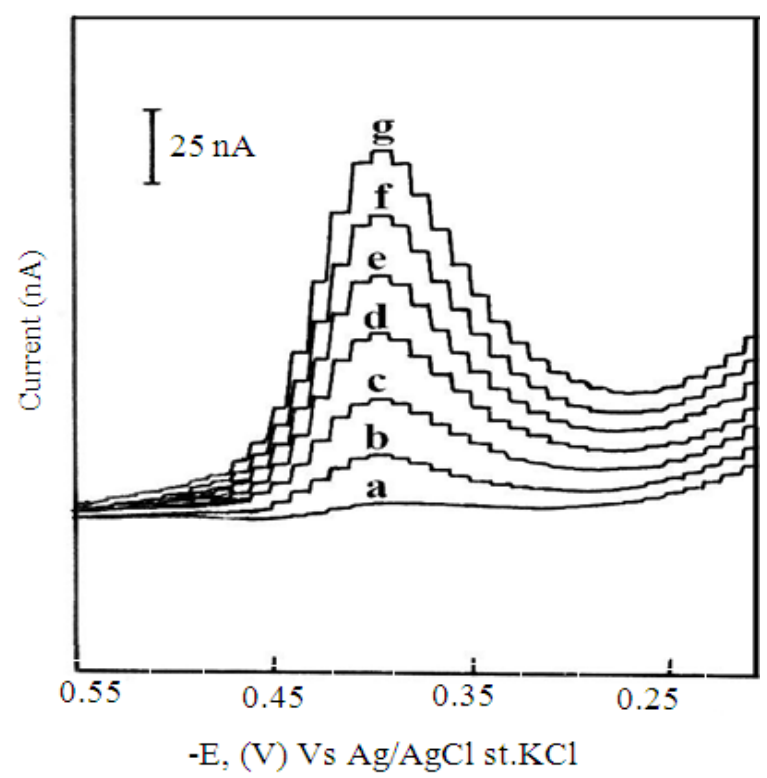

Fig. 1: DPAS Voltammograms of $\mathrm{Pb}$ (II) in $\mathrm{BC}_{2}$ sample in presence of $0.028 \mathrm{M}$ Briton-Robinson buffer solution, $\mathrm{pH} \sim 2.1$ at deposition potential $-0.55 \mathrm{~V}$ and different deposition times. (a) zero; (b) 10; (c) 20; (d) 30; (e) 40; (f) 50; (g) $60 \mathrm{sec}$
The effect of deposition potential of each metal ion was studied and it was observed that the highest and best shape peaks for $\mathrm{Cd}^{2+}, \mathrm{Pb}^{2+}$ and $\mathrm{Cu}^{2+}$ were at deposition potentials $-0.75,-0.55$ and $-0.25 \mathrm{~V}$ Vs. $\mathrm{Ag} / \mathrm{AgCl} / \mathrm{KCl}_{\text {sat. }}$. respectively.

The effect of deposition time on the oxidation peak signals of these metal ions was examined. Figure 1 shown differential pulse anodic stripping voltammograms of $\mathrm{Pb}(\mathrm{II})$ in $\mathrm{BC}_{2}$ in buffer solution at different deposition times. The optimal deposition times were selected for these metal ions of all sample solutions in a manner that linear relation must be established between deposition times and current signals and listed in Table 1-3.

DPAS voltammetric determination of Cd(II): Figure 2 represents the differential pulse anodic stripping voltammograms of $\mathrm{BC}_{3}$ sample solution in absence and in presence of the addition of standard cadmium ions in Briton-Robinson buffer solution of $\mathrm{pH} \sim 2$ 2.1. On plotting of peak current against concentrations for twelve clover honey sample solutions $\left(\mathrm{BC}_{\mathrm{x}}\right)$ in the same supporting electrolyte at the same conditions, straight lines are obtained (standard addition method) as shown in Fig. 3.

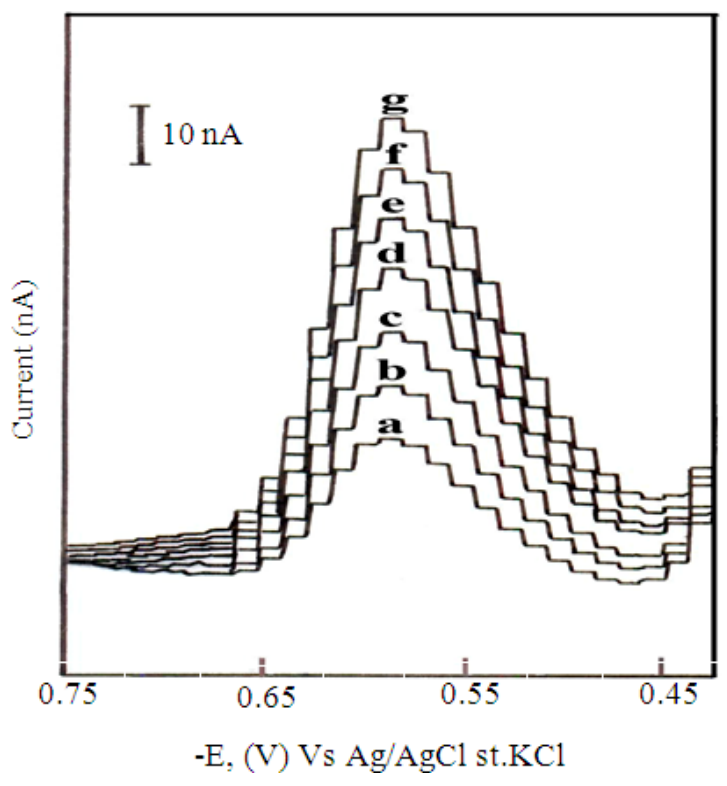

Fig. 2: DPAS Voltammograms of $\mathrm{Cd}(\mathrm{II})$ in $\mathrm{BC}_{3}$ sample spiked with different concentrations of $\mathrm{Cd}(\mathrm{II})$ ions in $0.028 \mathrm{M}$ Briton-Robinson buffer solution, $\mathrm{pH} \sim 2.1$ at deposition potential -0.75 $\mathrm{V}$ and deposition time $90 \mathrm{sec}$, (a) sample, S; (b) $\mathrm{S}+3 \times 10^{-9}$; (c) $\mathrm{S}+6 \times 10^{-9}$; (d) $\mathrm{S}+9 \times 10^{-9}$; (e) $\mathrm{S}+12 \times 10^{-9}$; (f) $\mathrm{S}+15 \times 10^{-9}$; (g) $\mathrm{S}+18 \times 10^{-9} \mathrm{M}$ $\mathrm{Cd}(\mathrm{II})$ 


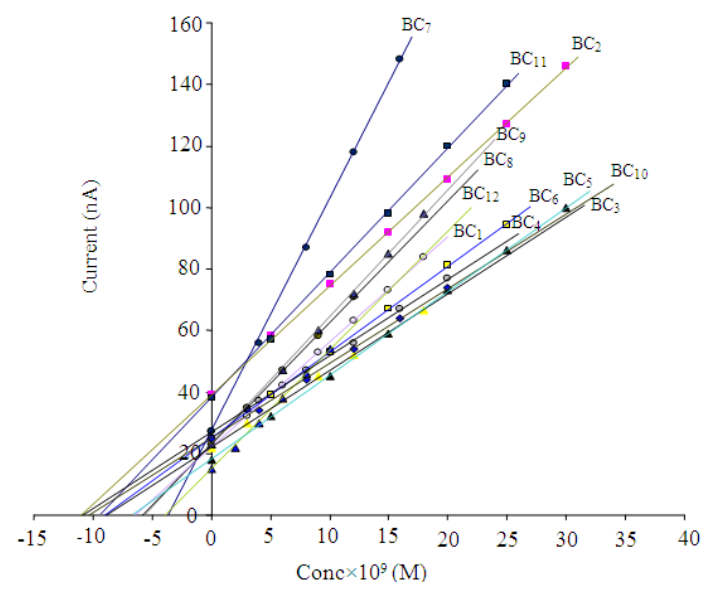

Fig. 3: Standard addition plots of $\mathrm{Cd}(\mathrm{II})$ in $\mathrm{BC}_{\mathrm{x}}$ samples: (1) $\mathrm{BC}_{1}$ at $120 \mathrm{sec}$; (2) $\mathrm{BC}_{2}$ at $45 \mathrm{sec}$; (3) $\mathrm{BC}_{3}$ at $90 \mathrm{sec}$; (4) $\mathrm{BC}_{4}$ at $90 \mathrm{sec}$; (5) $\mathrm{BC}_{5}$ at $120 \mathrm{sec} ;(6) \mathrm{BC}_{6}$ at $120 \mathrm{sec}$; (7) $\mathrm{BC}_{7}$ at $60 \mathrm{sec}$; (8) $\mathrm{BC}_{8}$ at $120 \mathrm{sec}$; (9) $\mathrm{BC}_{9}$ at $120 \mathrm{sec} ;(10)$ $\mathrm{BC}_{10}$ at $90 \mathrm{sec}$; (11) $\mathrm{BC}_{11}$ at $30 \mathrm{sec}$ (12): $\mathrm{BC}_{12}$ at $120 \mathrm{sec}$ at deposition potential $-0.75 \mathrm{~V}$ using (DPASV)

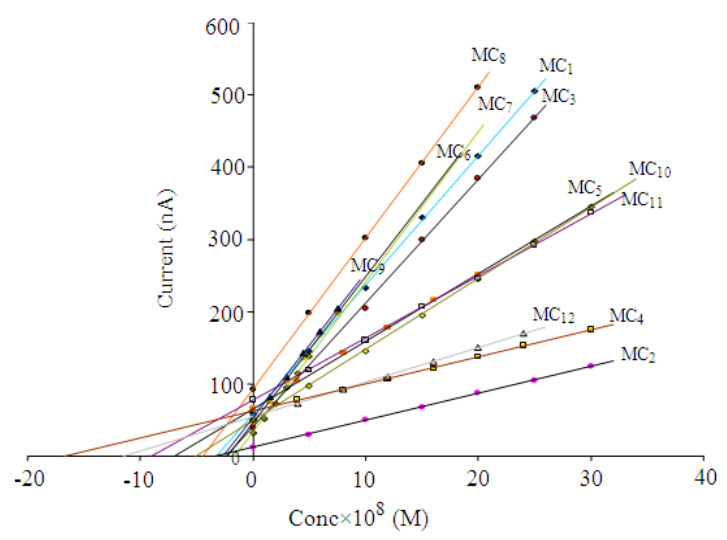

Fig. 4: Standard addition plots of $\mathrm{Pb}(\mathrm{II})$ in $\mathrm{MC}_{\mathrm{x}}$ Samples: (1) $\mathrm{MC}_{1}$ at $10 \mathrm{sec}$; (2): $\mathrm{MC}_{2}$ at $30 \mathrm{sec}$; (3) $\mathrm{MC}_{3}$ at $10 \mathrm{sec},(4) \mathrm{MC}_{4}$ at $30 \mathrm{sec}$; (5) $\mathrm{MC}_{5}$ at $60 \mathrm{sec} ;(6) \mathrm{MC}_{6}$ at $30 \mathrm{sec} ;(7) \mathrm{MC}_{7}$ at $45 \mathrm{sec} ;(8)$ MC8 at $10 \mathrm{sec} ;(9) \mathrm{MC}_{9}$ at $45 \mathrm{sec} ;(10): \mathrm{MC}_{10}$ at $15 \mathrm{sec}$; (11) $\mathrm{MC}_{11}$ at $15 \mathrm{sec}$; (12): $\mathrm{MC}_{12}$ at $20 \mathrm{sec}$ at deposition potential $-0.55 \mathrm{~V}$ using (DPASV)

From the interceptions of these lines with the concentration axis at zero current signals, one can calculate the concentration of $\mathrm{Cd}$ (II) in each sample. The concentration of $\mathrm{Cd}$ (II) ions in all samples (bee honey and edible molasses) under consideration using DPASV are listed in Table 1. The results indicate that, the concentrations of $\mathrm{Cd}$ (II) are ranged from 0.001 $0.077 \mu \mathrm{g} \mathrm{g}^{-1}$.

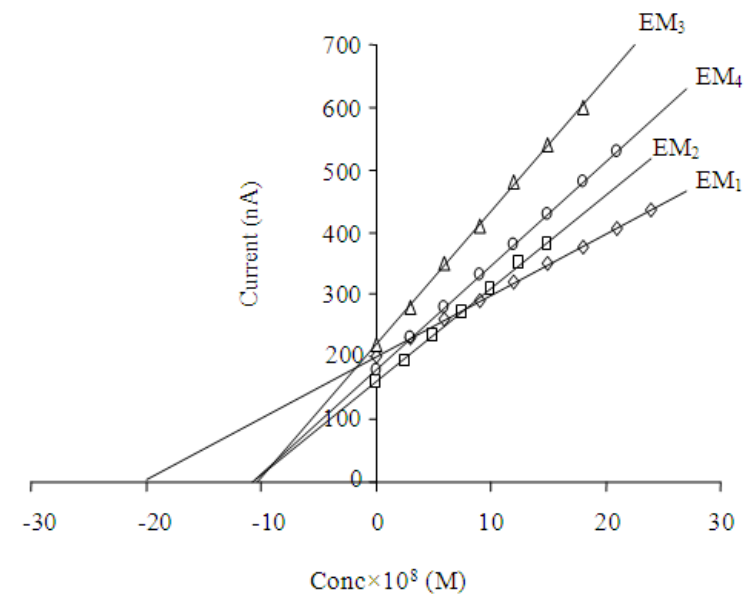

Fig. 5: Standard addition plots of $\mathrm{Cu}(\mathrm{II})$ in $\mathrm{EM}_{\mathrm{x}}$ samples at deposition potential $-0.25 \mathrm{~V}$, using (DPASV): (1) $\mathrm{EM}_{1}$ at $45 \mathrm{sec}$; (2) $\mathrm{EM}_{2}$ at $15 \mathrm{sec}$;

(3) $\mathrm{EM}_{3}$ at $30 \mathrm{sec} ;(4) \mathrm{EM}_{4}$ at $15 \mathrm{sec}$

DPAS voltammetric determination of $\mathbf{P b}(\mathrm{II})$ : Figure 4 shows the standard addition plots of i.p. against $\mathrm{Pb}$ (II) concentration for tweleve multi-flower honey sample solutions ( $\mathrm{MCx})$ in Briton-Robinson buffer solution of $\mathrm{pH} \sim 2.1$ at deposition potential 0.55 volt. From the interceptions of these straight lines with the concentration axis at zero current signal, the concentration of $\mathrm{Pb}(\mathrm{II})$ ions in all samples (bee honey and edible molasses) under consideration using DPASV was calculated and the resulting concentration values are listed in Table 2. The results indicate that, the concentration of $\mathrm{Pb}(\mathrm{II})$ ions are ranged from 0.006$1.640 \mu \mathrm{g} \mathrm{g}^{-1}$

DPAS voltammetric determination of $\mathrm{Cu}(\mathrm{II})$ : Figure 5 shows the standard addition plots of ip against $\mathrm{Cu}$ (II) concentration for four edible molasses sample solutions $\left(\mathrm{EM}_{\mathrm{x}}\right)$ in Briton-Robinson buffer solution of $\mathrm{pH} \sim 2.1$ at deposition potential -0.25 volt. From the interceptions of these straight lines with the concentration axis at zero current signal gives the concentration of $\mathrm{Cu}(\mathrm{II})$ in the voltammetric cell for each sample. After correction for the background current of blank experiments. The concentration of $\mathrm{Cu}$ (II) ions in all samples (bee honey and edible molasses) under consideration using DPASV are shown in Table 3. It was found that, the mean levels of $\mathrm{Cu}(\mathrm{II})$ ions are ranged from $0.085-0.987 \mu \mathrm{g} \mathrm{g}^{-1}$.

The precision and reproducibility of the selected procedurewere investigated by measuring the concentration of $\mathrm{Cd}(\mathrm{II}), \mathrm{Pb}$ (II) and $\mathrm{Cu}$ (II) in all bee honey and edible molasses samples under consideration for $(n=5)$. 
Am. J. Applied Sci., 7 (3): 315-322, 2010

Table 2: Lead content of different clover $\left(\mathrm{BC}_{\mathrm{x}}\right)$, multi-flower $\left(\mathrm{MC}_{\mathrm{x}}\right)$ citrus $\left(\mathrm{OC}_{\mathrm{x}}\right)$ honey samples and edible molasses samples $\left(\mathrm{EM}_{\mathrm{x}}\right)(\mathrm{a}$ mean value \pm standard deviation for $\mathrm{n}=5$ at the $95 \%$ confidence level)

\begin{tabular}{|c|c|c|c|c|c|c|}
\hline \multirow{3}{*}{$\begin{array}{l}\text { Samples } \\
\text { number }\end{array}$} & \multirow[b]{3}{*}{$\mathrm{T}_{\mathrm{d}}(\mathrm{sec})$} & \multirow{3}{*}{$\begin{array}{l}\text { Lead content } \\
(\text { mean } \pm \mathrm{SD}) \\
\mu \mathrm{g} \mathrm{g}^{-1}\end{array}$} & \multicolumn{3}{|c|}{ Regression parameter } & \multirow{3}{*}{$\begin{array}{l}\text { Cadmium content } \\
\text { (mean } \pm \text { SD) } \mu \mathrm{g} \mathrm{g}^{-} \\
\text {(GFAAS) }\end{array}$} \\
\hline & & & \multirow{2}{*}{$\begin{array}{l}\text { Correction } \\
\text { coefficient }\end{array}$} & \multicolumn{2}{|c|}{ Confidence } & \\
\hline & & & & Higher & Lower & \\
\hline$\overline{\mathrm{BC}_{1}}$ & 20 & $1.640 \pm 0.081$ & 0.9995 & 1.741 & 1.539 & $1.650 \pm 0.112$ \\
\hline $\mathrm{BC}_{2}$ & 40 & $0.616 \pm 0.021$ & 0.9993 & 0.642 & 0.589 & $0.618 \pm 0.014$ \\
\hline $\mathrm{BC}_{3}$ & 30 & $1.060 \pm 0.062$ & 0.9996 & 1.138 & 0.984 & $1.080 \pm 0.102$ \\
\hline $\mathrm{BC}_{4}$ & 30 & $0.595 \pm 0.043$ & 0.9995 & 0.645 & 0.545 & $0.586 \pm 0.031$ \\
\hline $\mathrm{BC}_{5}$ & 45 & $0.124 \pm 0.011$ & 1.0000 & 0.138 & 0.110 & $0.117 \pm 0.008$ \\
\hline $\mathrm{BC}_{6}$ & 60 & $0.093 \pm 0.009$ & 1.0000 & 0.104 & 0.082 & $0.095 \pm 0.007$ \\
\hline $\mathrm{BC}_{7}$ & 30 & $1.521 \pm 0.042$ & 0.9992 & 1.573 & 1.469 & $1.590 \pm 0.172$ \\
\hline $\mathrm{BC}_{8}$ & 60 & $0.263 \pm 0.032$ & 0.9990 & 0.303 & 0.223 & $0.270 \pm 0.019$ \\
\hline $\mathrm{BC}_{9}$ & 20 & $0.507 \pm 0.011$ & 0.9990 & 0.521 & 0.493 & $0.520 \pm 0.018$ \\
\hline $\mathrm{BC}_{10}$ & 45 & $0.692 \pm 0.081$ & 0.9992 & 0.792 & 0.591 & $0.695 \pm 0.063$ \\
\hline $\mathrm{BC}_{11}$ & 10 & $0.521 \pm 0.022$ & 0.9991 & 0.547 & 0.492 & $0.529 \pm 0.012$ \\
\hline $\mathrm{BC}_{12}$ & 30 & $0.187 \pm 0.013$ & 0.9999 & 0.203 & 0.171 & $0.195 \pm 0.014$ \\
\hline $\mathrm{MC}_{1}$ & 10 & $0.261 \pm 0.022$ & 0.9997 & 0.287 & 0.233 & $0.262 \pm 0.021$ \\
\hline $\mathrm{MC}_{2}$ & 30 & $0.267 \pm 0.044$ & 0.9997 & 0.322 & 0.212 & $0.272 \pm 0.032$ \\
\hline $\mathrm{MC}_{3}$ & 10 & $0.130 \pm 0.011$ & 0.9993 & 0.143 & 0.117 & $0.137 \pm 0.015$ \\
\hline $\mathrm{MC}_{4}$ & 30 & $1.610 \pm 0.121$ & 0.9994 & 1.762 & 1.462 & $1.624 \pm 0.202$ \\
\hline $\mathrm{MC}_{5}$ & 60 & $0.702 \pm 0.081$ & 0.9992 & 0.802 & 0.601 & $0.692 \pm 0.041$ \\
\hline $\mathrm{MC}_{6}$ & 30 & $0.178 \pm 0.006$ & 0.9998 & 0.186 & 0.171 & $0.176 \pm 0.034$ \\
\hline $\mathrm{MC}_{7}$ & 45 & $0.087 \pm 0.003$ & 0.9993 & 0.091 & 0.083 & $0.095 \pm 0.006$ \\
\hline $\mathrm{MC}_{8}$ & 10 & $0.404 \pm 0.022$ & 0.9993 & 0.431 & 0.377 & $0.419 \pm 0.018$ \\
\hline $\mathrm{MC}_{9}$ & 45 & $0.200 \pm 0.013$ & 0.9993 & 0.216 & 0.184 & $0.207 \pm 0.012$ \\
\hline $\mathrm{MC}_{10}$ & 15 & $0.438 \pm 0.081$ & 0.9992 & 0.539 & 0.337 & $0.450 \pm 0.032$ \\
\hline $\mathrm{MC}_{11}$ & 15 & $0.806 \pm 0.054$ & 0.9993 & 0.873 & 0.739 & $0.823 \pm 0.018$ \\
\hline $\mathrm{MC}_{12}$ & 20 & $1.065 \pm 0.104$ & 0.9992 & 1.194 & 0.936 & $1.078 \pm 0.123$ \\
\hline $\mathrm{OC}_{1}$ & 40 & $0.101 \pm 0.011$ & 0.9992 & 0.115 & 0.087 & $0.100 \pm 0.002$ \\
\hline $\mathrm{OC}_{2}$ & 40 & $0.324 \pm 0.021$ & 0.9995 & 0.351 & 0.298 & $0.337 \pm 0.019$ \\
\hline $\mathrm{EM}_{1}$ & 60 & $0.006 \pm 0.001$ & 0.9994 & 0.007 & 0.005 & $0.007 \pm 0.001$ \\
\hline $\mathrm{EM}_{2}$ & 45 & $0.051 \pm 0.004$ & 0.9994 & 0.056 & 0.046 & $0.053 \pm 0.004$ \\
\hline $\mathrm{EM}_{3}$ & 45 & $0.138 \pm 0.005$ & 0.9994 & 0.144 & 0.132 & $0.141 \pm 0.011$ \\
\hline $\mathrm{EM}_{4}$ & 45 & $0.201 \pm 0.011$ & 0.9991 & 0.215 & 0.187 & $0.209 \pm 0.015$ \\
\hline
\end{tabular}

The values of slopes, intercepts, confidence intervals, standard deviations and correlation coefficient obtained for all samples are listed in Table 1-3. These statistical parameter values indicate the reproducibility of the procedure for determination of each $\mathrm{Cd}(\mathrm{II}), \mathrm{Pb}$ (II) and $\mathrm{Cu}$ (II) in all samples in this Briton-Robinson buffer solution, $\mathrm{PH} \sim 2.1$.

Flame atomic absorption spectrometric determination of copper: Copper was determined by atomic absorption spectroscopy of the treated sample solutions at $324.7 \mathrm{~nm}$. The concentration values of each sample are listed in Table 3. It was found that the concentration of copper is ranged between 0.077$0.991 \mu \mathrm{g} \mathrm{g}^{-1}$. From Table 3 it was found that, the data obtained by stripping voltammetry are in a close agreement with those obtained by flame atomic absorption spectrometry. Flame atomic absorption spectrometric method was not obeyed for determination of cadmium and lead, so the concentration of each cadmium and lead is less than the detection limits of the FAAS technique.

Graphite furnace atomic absorption spectrometric determination of cadmium and lead: Cadmium and lead were determined by graphite furnace atomic absorption spectrometry at 228.9 and $283.2 \mathrm{~nm}$ respectively. The resulting data of cadmium and lead were listed in Table 1 and 2 respectively. From Table 1 and 2 , it was found that, the resulting data obtained by stripping voltammetry are in a close agreement with those obtained by graphite furnace atomic absorption spectrometry.

The foregoing results indicated that, copper, cadmium and lead contents in the bee honey and edible molasses samples are less than that permissible values which given by WHO and FAO and differ from each other's according to its botanical sources (only in case of bee honey), environment contamination, production and storage. 
Am. J. Applied Sci., 7 (3): 315-322, 2010

Table 3: Copper content of different clover $\left(\mathrm{BC}_{\mathrm{x}}\right)$, multi-flower $\left(\mathrm{MC}_{\mathrm{x}}\right)$ and citrus $\left(\mathrm{OC}_{\mathrm{x}}\right)$ honey samples and edible molasses samples $(\mathrm{EM})(\mathrm{a}$ mean value \pm standard deviation for $\mathrm{n}=5$ at the $95 \%$ confidence level)

\begin{tabular}{|c|c|c|c|c|c|c|}
\hline \multirow{3}{*}{$\begin{array}{l}\text { Samples } \\
\text { number }\end{array}$} & \multirow[b]{3}{*}{$\mathrm{T}_{\mathrm{d}}(\mathrm{sec})$} & \multirow{3}{*}{$\begin{array}{l}\text { Copper content } \\
(\text { mean } \pm \mathrm{SD}) \\
\mu \mathrm{g} \mathrm{g}^{-1}\end{array}$} & \multicolumn{3}{|c|}{ Regression parameter } & \multirow{3}{*}{$\begin{array}{l}\text { Cadmium content } \\
\text { (mean } \pm \text { SD) } \mu \mathrm{g} \mathrm{g}^{-1} \\
(\text { GFAAS) }\end{array}$} \\
\hline & & & \multirow{2}{*}{$\begin{array}{l}\text { Correction } \\
\text { coefficient }\end{array}$} & \multicolumn{2}{|c|}{ Confidence } & \\
\hline & & & & Higher & Lower & \\
\hline$\overline{\mathrm{BC}_{1}}$ & 40 & $0.497 \pm 0.052$ & 0.9996 & 0.559 & 0.435 & $0.503 \pm 0.011$ \\
\hline $\mathrm{BC}_{2}$ & 30 & $0.230 \pm 0.013$ & 0.9994 & 0.242 & 0.218 & $0.238 \pm 0.021$ \\
\hline $\mathrm{BC}_{3}$ & 45 & $0.242 \pm 0.021$ & 0.9994 & 0.267 & 0.217 & $0.252 \pm 0.009$ \\
\hline $\mathrm{BC}_{4}$ & 20 & $0.242 \pm 0.012$ & 0.9995 & 0.257 & 0.227 & $0.239 \pm 0.013$ \\
\hline $\mathrm{BC}_{5}$ & 30 & $0.696 \pm 0.091$ & 0.9997 & 0.809 & 0.583 & $0.701 \pm 0.042$ \\
\hline $\mathrm{BC}_{6}$ & 30 & $0.300 \pm 0.012$ & 0.9994 & 0.315 & 0.285 & $0.292 \pm 0.024$ \\
\hline $\mathrm{BC}_{7}$ & 45 & $0.193 \pm 0.009$ & 0.9998 & 0.204 & 0.182 & $0.189 \pm 0.018$ \\
\hline $\mathrm{BC}_{8}$ & 30 & $0.220 \pm 0.023$ & 0.9992 & 0.248 & 0.191 & $0.225 \pm 0.012$ \\
\hline $\mathrm{BC}_{9}$ & 45 & $0.286 \pm 0.013$ & 0.9993 & 0.302 & 0.269 & $0.287 \pm 0.017$ \\
\hline $\mathrm{BC}_{10}$ & 40 & $0.504 \pm 0.014$ & 0.9993 & 0.521 & 0.487 & $0.512 \pm 0.031$ \\
\hline $\mathrm{BC}_{11}$ & 10 & $0.747 \pm 0.051$ & 0.9994 & 0.811 & 0.684 & $0.734 \pm 0.019$ \\
\hline $\mathrm{BC}_{12}$ & 30 & $0.308 \pm 0.008$ & 0.9995 & 0.318 & 0.298 & $0.301 \pm 0.024$ \\
\hline $\mathrm{MC}_{1}$ & 15 & $0.987 \pm 0.121$ & 0.9992 & 1.137 & 0.837 & $0.991 \pm 0.051$ \\
\hline $\mathrm{MC}_{2}$ & 30 & $0.255 \pm 0.023$ & 0.9993 & 0.284 & 0.226 & $0.251 \pm 0.022$ \\
\hline $\mathrm{MC}_{3}$ & 10 & $0.085 \pm 0.012$ & 0.9995 & 0.099 & 0.071 & $0.077 \pm 0.004$ \\
\hline $\mathrm{MC}_{4}$ & 30 & $0.165 \pm 0.013$ & 0.9991 & 0.181 & 0.149 & $0.177 \pm 0.021$ \\
\hline $\mathrm{MC}_{5}$ & 15 & $0.171 \pm 0.032$ & 0.9996 & 0.211 & 0.131 & $0.174 \pm 0.023$ \\
\hline $\mathrm{MC}_{6}$ & 15 & $0.813 \pm 0.093$ & 0.9994 & 0.927 & 0.697 & $0.828 \pm 0.061$ \\
\hline $\mathrm{MC}_{7}$ & 30 & $0.398 \pm 0.041$ & 0.9997 & 0.449 & 0.347 & $0.407 \pm 0.015$ \\
\hline $\mathrm{MC}_{8}$ & 10 & $0.555 \pm 0.014$ & 0.9992 & 0.572 & 0.538 & $0.552 \pm 0.023$ \\
\hline $\mathrm{MC}_{9}$ & 30 & $0.512 \pm 0.082$ & 0.9996 & 0.614 & 0.411 & $0.525 \pm 0.051$ \\
\hline $\mathrm{MC}_{10}$ & 45 & $0.161 \pm 0.013$ & 0.9993 & 0.177 & 0.145 & $0.158 \pm 0.011$ \\
\hline $\mathrm{MC}_{11}$ & 20 & $0.335 \pm 0.021$ & 0.9997 & 0.361 & 0.309 & $0.335 \pm 0.043$ \\
\hline $\mathrm{MC}_{12}$ & 30 & $0.303 \pm 0.013$ & 0.9993 & 0.319 & 0.287 & $0.300 \pm 0.017$ \\
\hline $\mathrm{OC}_{1}$ & 30 & $0.393 \pm 0.032$ & 0.9991 & 0.433 & 0.353 & $0.401 \pm 0.009$ \\
\hline $\mathrm{OC}_{2}$ & 45 & $0.275 \pm 0.013$ & 0.9998 & 0.291 & 0.259 & $0.292 \pm 0.013$ \\
\hline $\mathrm{EM}_{1}$ & 45 & $0.646 \pm 0.033$ & 0.9996 & 0.687 & 0.605 & $0.656 \pm 0.021$ \\
\hline $\mathrm{EM}_{2}$ & 15 & $0.309 \pm 0.011$ & 0.9990 & 0.323 & 0.295 & $0.323 \pm 0.012$ \\
\hline $\mathrm{EM}_{3}$ & 30 & $0.301 \pm 0.013$ & 0.9995 & 0.317 & 0.285 & $0.298 \pm 0.012$ \\
\hline $\mathrm{EM}_{4}$ & 15 & $0.315 \pm 0.009$ & 1.0000 & 0.326 & 0.304 & $0.322 \pm 0.016$ \\
\hline
\end{tabular}

\section{CONCLUSION}

The use of Briton-Robinson buffer solution after a wet digestion method for determination of $\mathrm{Cd}(\mathrm{II})$, $\mathrm{Pb}$ (II) and $\mathrm{Cu}(\mathrm{II})$ ions by differential pulse anodic stripping voltammetry is selected method for determination of these metal ions in bee honey and edible molasses samples. This procedure presented a better detection limit than others, which reported in the literature. This method is also allowed $\mathrm{Cd}, \mathrm{Pb}$ and $\mathrm{Cu}$ determination in the same voltammetric cell without external addition of base to change the $\mathrm{pH}$ value. The time of determination is shorter than that by other methods. From the foregoing results, one can concluded that, the application of standard addition method for anodic stripping voltammetric determination of divalent cadmium, lead and copper in honey samples as well as in edible molasses samples is suitable and successful.

\section{REFERENCES}

Ajtony, Z., L. Bencs, R. Haraszi, J. Szigeti and N. Szoboszlai, 2007. Study on the simultaneous determination of some essential and toxic trace elements in honey by multi-element graphite furnace atomic absorption spectrometry. Talanta, 71: 683-690.
Antonescu, C. and C. Mateescu, 2001. Environmental pollution and its effects on honey quality. Roman. Biotechnol. Lett., 6: 371-379.

Batuman, V., J.K. Maesaka, B. Haddad, E.Tepper and E. Landy et al., 1981. The role of lead in gout nephropathy. N. Engl. J. Med., 304: 520-523.

Bogdanov, S., A. Imdorf, J.D. Charriere, P. Fluri and V. Kilchenmann, 2003. The Contaminants of the bee Colony. Swiss Bee Research Center, Bern, Switzerland.

http://hirschbachapiary.com/Documents/The\%20co ntaminants $\% 20$ of $\% 20$ the $\% 20$ bee $\% 20$ colony.pdf

Bogdanov, S., V. Kilchenmann and P. Fluri, U. Buhler and P. Lavanchy, 1999. Influence of organic acids and components of essential oils on honey taste. Am. Bee J., 139: 61-63.

Buldini, P.L., S. Cavalli, A. Mevoli and J.L. Sharma, 2001. Ion chromatographic and voltammetric determination of heavy and transition metals in honey. Food Chem., 73: 487-495.

Caroli, S., G. Forte, A.L. Iamiceli and B. Galoppi, 1999. Determination of essential and potentially toxic trace elements in honey by inductively coupled plasma-based techniques. Talanta, 50: 327-336. 
Clarkson, T.W., 1988. Biological Monitoring of Toxic Metals. 1st Edn., Plenum Press, USA., ISBN-10: 0306428091 , pp: 686.

Dadant and Sons, 1992. The Hive and the Honey Bee. Dadant and Sons, Hamilton, Illinois, USA., ISBN: 10: 0915698099, pp: 1324.

Ensafi, A.A., T. Khayamian and S.S. Khaloo, 2004. Application of adsorptive cathodic differential pulse stripping method for simultaneous determination of copper and molybdenum using pyrogallol red. Anal. Chim. Acta, 505: 201-207.

Fernandez, M.C., E. Subra and A. Ortiz, 1994 Honey, environmental indicator. Environmental practices for quality agriculture. Proceeding of the Congress of the Spanish Society of Organic Agriculture, (SSOA'94) Toledo, Spain, pp: 37-44.

Fernandez-Torres, R., J.L. Perez-Bernal, M.A. BelloLopez, M. Callejon-Mochon, J.C. Jimenez-Sanchez and A. Guiraum-Perez, 2005. Mineral content and botanical origin of Spanish honeys. Talanta, 65: 686-691.

Fredes, C. and G. Montenegro, 2006. Heavy metals and other trace elements contents in Chilean honey. Cien. Inv. Agric., 33: 50-58.

Ioannidou, M.D., G.A. Zachariadis, A.N. Anthemidis and J.A. Stratis, 2005. Direct determination of toxic trace metals in honey and sugars using inductively coupled plasma atomic emission spectrometry. Talanta, 65: 92-97.

Kump, P., M. Necemer and J. Snajder, 1996. Determination of trace elements in bee honey, pollen and tissue by total reflection and radioisotope X-ray fluorescence spectrometry. Spectrochim. Acta Part B: Atomic Spectrosc., 51: 499-507.

Lachman, J., D. Kolihova, D. Miholova, J. Kosata, D. Titera and K. Kult, 2007. Analysis of minority honey components: Possible use for the evaluation of honey quality. Food Chem., 101: 973-979.

Li, Y., F. Wahdat and R. Neeb, 1995. Digestion-free determination of heavy metals $(\mathrm{Pb}, \mathrm{Cd}, \mathrm{Cu})$ in honey using anodic stripping differential pulse voltammetry and potentiometric stripping analysis. Fresenius J. Anal. Chem., 351: 678-682.

Lide, D.R., 2005. CRC Handbook of Chemistry and Physics. CRC, 86th Edn., Florence, Kentucky, USA., ISBN-13: 9780849304866, pp: 2544.

Munoz, E. and S. Palmero, 2006. Determination of heavy metals in honey by potentiometric stripping analysis and using a continuous flow methodology. Food Chem., 94: 478-483.
Packer, A.P. and M.F. Gine, 2001. Analysis of undigested honey samples by isotope dilution inductively coupled plasma mass spectrometry with direct injection nebulization (ID-ICP-MS). Spectrochim. Acta Part B, 56: 69-75.

Rodriguez-Garcia, J.C., J. Barciela-Garcia, C. HerreroLatorre, M. Freire-Rodriguez, S. Garcia-Martin and R.M. Pena-Crecente, 2003. Comparison of palladium-magnesium nitrate and ammonium dihydrogenphosphate modifiers for cadmium determination in honey samples by electrothermal atomic absorption spectrometry. Talanta, 61: 509-517.

Sanna, G., M. Pilo, P.C. Piu, A. Tapparo and R. Seeber, 2000. Determination of heavy metals in honey by anodic stripping voltammetr at microelectrodes. Anal. Chim, Acta, 415: 165-173.

Simon, J.A. and E.S. Hudes, 1999. Relationship of ascorbic acid to blood lead levels. J. Am. Med. Assoc., 281: 2289-2293.

Taddia, M., A. Musiani and S. Schiavi, 2004. Determination of heavy metals in honey by Zeeman electrothermal atomic absorption spectrometry. Ann. di Chim., 94: 107-111.

Terrab, A., A.F. Recamales, M.L. González-Miret and F.J. Heredia, 2005. Contribution to the study of avocado honeys by their mineral contents using inductively coupled plasma optical emission spectrometry. Food Chem., 92: 305-309.

Tuzen, M. and M. Soylak, 2005. Trace heavy metal levels in microwave digested honey samples from middle Anatolia, Turkey. J. Food Drug Anal., 13: 343-347.

Vinas P., I. Lipez-Garcia, M. Lanzon and M. HernandezCordoba, 1997. Direct determination of lead, cadmium, zinc, and copper in honey by electrothermal atomic absorption spectrometry using hydrogen peroxide as a matrix modifier. Agric. Food Chem., 45: 3952-3956.

Vogel, A.I. and J. Basset, 1978. A Textbook of Quantitative Inorganic Analysis. 4th Edn., Longman, London, pp: 925.

Wilson, L.D., 1998. Nutritional Balancing and Hair Mineral Analysis. Lawrance Wilson, ISBN: 10: 0962865745, pp: 389.

Yilmaz, H. and O. Yavuz, 1999. Content of some trace metals in honey from south-eastern Anatolia. Food Chem., 65: 475-476. 